\title{
Histone deacetylase inhibitors induce apoptosis in human eosinophils and neutrophils
}

Hannu Kankaanranta ${ }^{1,2^{*}}$, Mirkka Janka-Junttila ${ }^{1}$, Pinja IImarinen-Salo ${ }^{1}$, Kazuhiro Ito ${ }^{3}$, Ulla Jalonen ${ }^{1}$, Misako Ito ${ }^{3}$, Ian M Adcock ${ }^{3}$, Eeva Moilanen ${ }^{1}$, Xianzhi Zhang ${ }^{1}$

\begin{abstract}
Background: Granulocytes are important in the pathogenesis of several inflammatory diseases. Apoptosis is pivotal in the resolution of inflammation. Apoptosis in malignant cells is induced by histone deacetylase (HDAC) inhibitors, whereas HDAC inhibitors do not usually induce apoptosis in non-malignant cells. The aim of the present study was to explore the effects of HDAC inhibitors on apoptosis in human eosinophils and neutrophils.

Methods: Apoptosis was assessed by relative DNA fragmentation assay, annexin-V binding, and morphologic analysis. HDAC activity in nuclear extracts was measured with a nonisotopic assay. HDAC expression was measured by real-time PCR.

Results: A HDAC inhibitor Trichostatin A (TSA) induced apoptosis in the presence of survival-prolonging cytokines interleukin-5 and granulocyte-macrophage colony stimulating factor (GM-CSF) in eosinophils and neutrophils. TSA enhanced constitutive eosinophil and neutrophil apoptosis. Similar effects were seen with a structurally dissimilar HDAC inhibitor apicidin. TSA showed additive effect on the glucocorticoid-induced eosinophil apoptosis, but antagonized glucocorticoid-induced neutrophil survival. Eosinophils and neutrophils expressed all HDACs at the mRNA level except that HDAC5 and HDAC11 mRNA expression was very low in both cell types, HDAC8 mRNA was very low in neutrophils and HDAC9 mRNA low in eosinophils. TSA reduced eosinophil and neutrophil nuclear HDAC activities by $~ 50-60 \%$, suggesting a non-histone target. However, TSA did not increase the acetylation of a non-histone target NF- $\kappa$ B p65. c-jun-N-terminal kinase and caspases 3 and 6 may be involved in the mechanism of TSA-induced apoptosis, whereas PI3-kinase and caspase 8 are not.
\end{abstract}

Conclusions: HDAC inhibitors enhance apoptosis in human eosinophils and neutrophils in the absence and presence of survival-prolonging cytokines and glucocorticoids.

\section{Background}

Eosinophils are important inflammatory cells involved in the pathogenesis of asthma and exacerbations of chronic obstructive pulmonary disease (COPD) [1]. Accumulation and activation of neutrophils at the inflamed site is involved in the pathogenesis of COPD, severe asthma and asthma exacerbations [1]. The process of apoptosis of granulocytes is believed to be pivotal in the resolution of inflammation, since it determines the rapid clearance of intact senescent eosinophils and neutrophils, thus providing an injury-limiting granulocyte clearance mechanism $[2,3]$. Eosinophil and neutrophil apoptosis

\footnotetext{
* Correspondence: blhaka@uta.fi

'The Immunopharmacology Research Group, Medical School, FIN-33014, University of Tampere and Research Unit, Tampere University Hospital, Tampere, Finland
}

(c) 2010 Kankaanranta et al; licensee BioMed Central Ltd. This is an Open Access article distributed under the terms of the Creative Commons Attribution License (http://creativecommons.org/licenses/by/2.0), which permits unrestricted use, distribution, and reproduction in any medium, provided the original work is properly cited. can be modulated by glucocorticoids and death receptors i.e. Fas and inhibited by survival-prolonging cytokines such as interleukin-5 (IL-5) and granulocytemacrophage colony-stimulating factor (GM-CSF) $[2,3]$. We, and others, have previously shown that eosinophil apoptosis is delayed in patients with asthma or inhalant allergy [4-6]. However, the mechanisms of apoptosis in these cells remain largely unknown. In fact, it is not even known whether the main event controlling eosinophil apoptosis is upregulation or downregulation of genes [3].

Histone acetylation regulates inflammatory gene expression and also plays a role in diverse functions such as DNA repair and cell proliferation and apoptosis $[7,8]$. In the resting cell, DNA is tightly compacted around core histones. Specific residues within the N-terminal tails of 
histones can be posttranslationally modified by acetylation, leading to release of the tightly wound DNA. Conversely, histone deacetylation is thought to re-establish the tight nucleosomal structure $[7,8]$. Histone acetylation is regulated by a dynamic balance between histone acetyltransferases (HAT) and histone deacetylases (HDAC). Changes in histone acetylation patterns have been reported in many human diseases, particularly cancer, and investigators have used HDAC inhibitors against many malignancies. HDAC inhibitors induce apoptotic cell death in a number of tumor cell types $[9,10]$. In contrast, normal cells are usually resistant to cell death caused by HDAC inhibitors $[9,10]$.

However, recent in vivo data in animal models suggest that HDAC inhibitors may have potential to act as antiinflammatory and anti-allergic agents. For example, evidence from an adjuvant-induced arthritis-model suggests that HDAC inhibitors may be useful in rheumatoid arthritis [11]. Recently, Choi and coworkers [12] demonstrated that trichostatin A (TSA) blocked ovalbumin (OVA) -induced airway hyper-responsiveness, as well as reduced the numbers of eosinophils in lavage fluid. Even though HDAC inhibitors do not usually induce apoptosis in non-malignant cells, the promising in vivo findings prompted us to test the effects of HDAC inhibitors on apoptosis of terminally differentiated primary cells such as human eosinophils and neutrophils.

\section{Methods}

\section{Blood donors}

For neutrophil experiments blood was obtained from healthy donors. For eosinophil experiments, blood (50$100 \mathrm{ml}$ ) was obtained from eosinophilic individuals. However, patients with hypereosinophilic syndrome were excluded. All subjects gave informed consent to a study protocol approved by the ethical committee of Tampere University Hospital (Tampere, Finland).

\section{Neutrophil and eosinophil isolation}

Neutrophils from venous blood were isolated under sterile conditions as previously reported [13,14]. Neutrophil populations with purity of $>98 \%$ were accepted for the experiments. The neutrophils were resuspended at 2 $\times 10^{6}$ cells $/ \mathrm{ml}$, cultured for $16 \mathrm{~h}\left(37^{\circ} \mathrm{C} ; 5 \% \mathrm{CO}_{2}\right)$ in RPMI 1640 (Dutch modification) with 10\% fetal calf serum plus antibiotics. Eosinophils were purified by using immunomagnetic anti-CD16 antibody conjugated beads as previously described [5,15-17]. The purity of eosinophil population was $>99 \%$. The eosinophils were resuspended at $1 \times 10^{6}$ cells $/ \mathrm{ml}$, cultured $\left(37^{\circ} \mathrm{C}, 5 \%\right.$ $\mathrm{CO}_{2}$ ) for $18 \mathrm{~h}$ (morphological and Annexin-V assays) or $40 \mathrm{~h}$ (relative DNA fragmentation assay) in the absence or presence of cytokines, glucocorticoids and HDAC inhibitors in RPMI 1640 (Dutch modification) with 10\% fetal calf serum plus antibiotics in 96-well plates.

\section{Macrophage cultures}

J774.2 macrophages (The European Collection of Cell Cultures, Porton Down, Wiltshire, UK) were cultured at $37^{\circ} \mathrm{C}, 5 \% \mathrm{CO} 2$ atmosphere, in Dulbecco's Modified Eagle's Medium with Ultraglutamine 1 (DMEM/U1) supplemented with $5 \%$ of heat inactivated foetal bovine serum, penicillin $(100 \mathrm{U} / \mathrm{ml})$, streptomycin $(100 \mu \mathrm{g} / \mathrm{ml})$ and amphotericin B $(250 \mathrm{ng} / \mathrm{ml})$. Cells were seeded on 24 well plates and grown to confluence prior to experiments. Cells were cultured for $24 \mathrm{~h}$ in the presence or absence of various concentrations of TSA or lipopolysaccharide (LPS; $10 \mathrm{ng} / \mathrm{ml}$ ) and ammonium pyrrolidinedithiocarbamate (PDTC; $100 \mu \mathrm{M}$ ), whereafter medium was removed, cells were washed once with phosphate-buffered saline (PBS) and double-stained with Annexin-V and PI.

\section{Apoptosis assays}

Apoptosis was determined by propidium iodide staining of DNA fragmentation and flow cytometry (FACScan, Becton Dickinson, San Jose, CA) as previously described [15-17]. The cells showing decreased relative DNA content were considered apoptotic $[15,16]$. Annexin V-binding assay was performed as previously described $[14,16]$ and cells showing positive staining with Annexin-V (i.e. both early apoptotic Annexin $\mathrm{V}^{+\mathrm{ve}} / \mathrm{PI}^{-\mathrm{ve}}$ and late apoptotic/secondary necrotic cells: Annexin $\mathrm{V}^{+\mathrm{ve}} / \mathrm{PI}^{+\mathrm{ve}}$ ) were considered to be apoptotic. For morphological analysis, eosinophils or neutrophils were centrifuged onto cytospin slides (1000 rpm, $7 \mathrm{~min}$ ) and stained with MayGrünwald-Giemsa after fixation in methanol. The cells showing typical features of apoptosis such as cell shrinkage, nuclear coalescence and nuclear chromatin condensation were considered as apoptotic $[5,15,16]$.

\section{Western blotting}

Eosinophils were suspended at $10^{6}$ cells $/ \mathrm{ml}$ and cultured at $+37^{\circ} \mathrm{C}$ for $1 \mathrm{~h}$ in the absence and presence of DMSO (solvent control), TSA (330 nM) or GM-CSF (0.1 ng/ $\mathrm{ml})$. Thereafter the samples were centrifuged at $1000 \mathrm{~g}$ for $1 \mathrm{~min}$. The cell pellet was lysed by incubating for 15-30 min in $40 \mu \mathrm{l}$ of ice-cold RIPA buffer with protease inhibitors. The sample was centrifuged at $12000 \mathrm{~g}$ for $5 \mathrm{~min}$ and the debris was carefully removed. Samples were mixed into SDS (sodium dodecyl sulfate)-containing loading buffer and stored at $-20^{\circ} \mathrm{C}$ until the Western blot analysis. The protein sample $(25-30 \mu \mathrm{g})$ was loaded onto $10 \%$ SDS-polyacrylamide electrophoresis gel and electrophoresed for $2 \mathrm{~h}$ at $120 \mathrm{~V}$. The separated proteins were transferred to Hybond enhanced chemiluminescence nitrocellulose membrane 
(Amersham Biosciences UK, Ltd., Little Chalfont, Buckinghamshire, UK) with a semidry blotter at $2 \mathrm{~mA} \mathrm{~cm}^{-2}$ for $60 \mathrm{~min}$. After transfer, the membranes were blocked by $5 \%$ bovine serum albumin (BSA) in TBST $(20 \mathrm{mM}$ Tris base $\mathrm{pH}$ 7.6, $150 \mathrm{mM} \mathrm{NaCl}, 0.1 \%$ Tween-20) for 1 $\mathrm{h}$ at room temperature and incubated with the specific primary antibody overnight at $+4^{\circ} \mathrm{C}$ in the blocking solution. The membrane was thereafter washed $3 \times$ with TBST for $5 \mathrm{~min}$, incubated for $30 \mathrm{~min}$ at room temperature with the secondary antibody in the blocking solution and washed $3 \times$ with TBST for $5 \mathrm{~min}$. Bound antibody was detected by using SuperSignal West Dura chemiluminescent substrate (Pierce, Cheshire, UK) and FluorChem 8800 imaging system (Alpha Innotech Corporation, San Leandro, CA, USA). The chemiluminescent signal was quantified by using the FluorChem software version 3.1.

\section{HDAC colorimetric activity assay}

Nuclear extracts were prepared from $5 \times 10^{6}$ cells using a modification of method of Dignam et al [18]. Briefly, isolated cells were washed with cold PBS and suspended in hypotonic buffer A (20 mM HEPES-KOH, pH 7.9, $3.0 \mathrm{mM} \mathrm{MgCl} 2,20 \mathrm{mM} \mathrm{KCl}$ and protease inhibitor mixture). After incubation for $30 \mathrm{~min}$ on ice, 0.2 volumes of $10 \%$ igepal CA-30 (v/v) was added, and the cells were vortexed for $30 \mathrm{~s}$. Eosinophils were further processed by Dounce tissue homogenizer. Following centrifugation at $12,000 \mathrm{~g}$ for $10 \mathrm{~s}$, the supernatant was discarded and the pellet was washed in $100 \mu \mathrm{l}$ of buffer A without Igepal and re-centrifuged. The pelleted nuclei were resuspended in buffer $\mathrm{C}$ (40 $\mathrm{mM}$ HEPES-KOH, $\mathrm{pH} 7.9,50 \%$ glycerol, $840 \mathrm{mM} \mathrm{NaCl}, 3 \mathrm{mM} \mathrm{MgCl}_{2}, 0.2$ mM EDTA and protease inhibitor cocktail tablet solution) and incubated for $20 \mathrm{~min}$ on ice. Nuclei were vortexed for $1 \mathrm{~min}$ and nuclear extracts were obtained by centrifugation at $12,000 \mathrm{~g}$ for $2 \mathrm{~min}, 4^{\circ} \mathrm{C}$ and stored at $-76^{\circ} \mathrm{C}$ until use.

HDAC colorimetric activity assay was carried out according to the manufacturer's instructions. HDAC inhibitors and assay buffer were mixed to the wells of the microtiter plate. Nuclear extracts were added to appropriate wells and equilibrated to assay temperature $\left(37^{\circ} \mathrm{C}\right)$. Color de $\mathrm{Lys}^{\mathrm{TM}}$ substrate was added and mixed in each well to initiate HDAC reactions and incubated at $37^{\circ} \mathrm{C}$ for $30 \mathrm{~min}$. Color de $\mathrm{Lys}^{\mathrm{Ts}}$ developer was added to stop HDAC reaction. The mixture was incubated at $37^{\circ}$ $\mathrm{C}$ for $15 \mathrm{~min}$ and read in microtiter-plate reader (Wallac, Turku, Finland) at $405 \mathrm{~nm}$.

\section{Real-time PCR}

To isolate mRNA from human eosinophils and neutrophils, the cells were first sedimented whereafter TRI REAGENT $\left(1.0 \mathrm{ml} / 5 \times 10^{6}\right.$ eosinophils $)$ was added. mRNA was isolated according to the manufacturer's instructions and reverse transcription of RNA to cDNA was performed as described previously [19].

Gene transcript levels of HDAC1 to 11 and the housekeeping genes glyceraldehydes-3 phosphate dehydrogenase (GAPDH) and GLB2L1 were quantified by real-time PCR using a Taqman master mix (Applied Biosystems, Foster City, CA) on a Rotor-Gene 3000 PCR apparatus (Corbett Research, N.S.W., Australia). The primer pairs were purchased from Applied Biosystems. Variations in cDNA concentration between different samples were corrected using the housekeeping gene. The relative amount of gene transcript present was calculated and normalized by dividing the calculated value for the gene of interest by the housekeeping gene value.

\section{Materials}

Reagents were obtained as follows: apicidin, MC-1293 and MS-275 (Alexis, Lausen, Switzerland), CD95 monoclonal antibody (clone $\mathrm{CH}-11$; Immunotech, Marseille, France), NF-kB p65 and acetyl-NF-kB p65 (Lys310) antibodies (Cell Signaling Technology, Inc., Danvers, USA), fluticasone, igepal CA-630, LPS, PDTC and trichostatin A (Sigma Chemical Co., St. Louis, MO, USA), Z-VE (OMe)ID(OMe)-FMK, Z-D(OMe)QMD(OMe)-FMK, IETD-CHO, Q-VD-OPh and LY294002 (Calbiochem, San Diego, USA), HDAC colorimetric activity kit (Biomol, Plymouth Meeting, USA), mometasone (ScheringPlough, Kenilworth, NJ), DMEM/U1 (Lonza Verviers SPRL, Verviers, Belgium), penicillin, streptomycin and amphotericin (Invitrogen, Paisley UK), wortmannin (Merck, Darmstadt, Germany) and TRI REAGENT (Molecular Research Center, Inc., Cincinnati, OH). Other reagents were obtained as previously described $[5,13-17,19]$. Stock solutions of budesonide $(50 \mathrm{mM})$ were prepared in ethanol. The final concentration of ethanol in the culture was $0.2 \%$. Stock solutions of HDAC inhibitors were prepared in DMSO. The final concentration of DMSO in the culture was $0.5 \%$. A similar concentration of DMSO was used in control experiments.

\section{Statistics}

Results are expressed as Mean \pm SEM. The $\mathrm{EC}_{50}$ was defined as the concentration of drug producing $50 \%$ of its maximal effect. Statistical significance was calculated by analysis of variance for repeated measures supported by Student-Newman-Keuls multiple comparisons test or Dunnett test. HDAC expression levels obtained by quantitative PCR were compared using Mann-Whitney U-test. Differences were considered significant when P $<0.05$. 


\section{Results}

HDAC inhibitors enhance eosinophil apoptosis in the presence of survival-prolonging cytokines

IL-5 inhibited human eosinophil apoptosis in a concentration-dependent manner and maximal inhibition of apoptosis was obtained at $0.3 \mathrm{ng} / \mathrm{ml}$ concentration (percentage of apoptotic cells $41 \pm 3$ and $8 \pm 1$ in the absence and presence of IL-5, respectively, $\mathrm{n}=5, \mathrm{P}<$ $0.001)$. TSA (330 nM) enhanced apoptosis in the presence of IL-5 as evidenced by an increase in the number of cells showing decreased relative DNA content (Figure 1A-C). The effect of TSA was concentration-dependent and the $\mathrm{EC}_{50}$ value for the enhancement of apoptosis in the presence of IL-5 was $92 \pm 8 \mathrm{nM}, \mathrm{n}=6$; Figure 1D). This increase in the number of apoptotic cells was confirmed by showing increased phosphatidylserine expression on the outer leaflet of cell membrane of IL-5treated cells, i.e. the percentage of Annexin- $\mathrm{V}$-positive cells (Figure 1E-H). Furthermore, an increase in the
Table 1 The $\mathrm{EC}_{50}$ Values for the effects of trichostatin A on apoptosis in eosinophils and neutrophils.

\begin{tabular}{llll}
\hline & \multicolumn{3}{c}{$\mathrm{EC}_{\mathbf{5 0}}$ (nM) } \\
\cline { 2 - 4 } Apoptosis & Eosinophils & neutrophils & P value \\
\hline GM-CSF & & & \\
$\quad 0.01 \mathrm{ng} / \mathrm{ml}$ & $79 \pm 2$ & & \\
$\quad 0.1 \mathrm{ng} / \mathrm{ml}$ & $102 \pm 1$ & & 0.0042 \\
$\quad 10 \mathrm{ng} / \mathrm{ml}$ & $93 \pm 1$ & $123 \pm 9$ & \\
IL-5 & $92 \pm 8$ & & 0.0007 \\
Constitutive & $34 \pm 10$ & $97 \pm 22$ & 0.026 \\
Budesonide & $32 \pm 17$ & $99 \pm 7$ & 0.017 \\
Fluticasone & $47 \pm 15$ & $100 \pm 11$ & $<0.0001$ \\
Mometasone & $20 \pm 5$ & $87 \pm 9$ & \\
Fas & $31 \pm 10$ & & \\
\hline
\end{tabular}

Values are the mean \pm S.E.M. of six duplicate experiments with cells isolated from different donors.

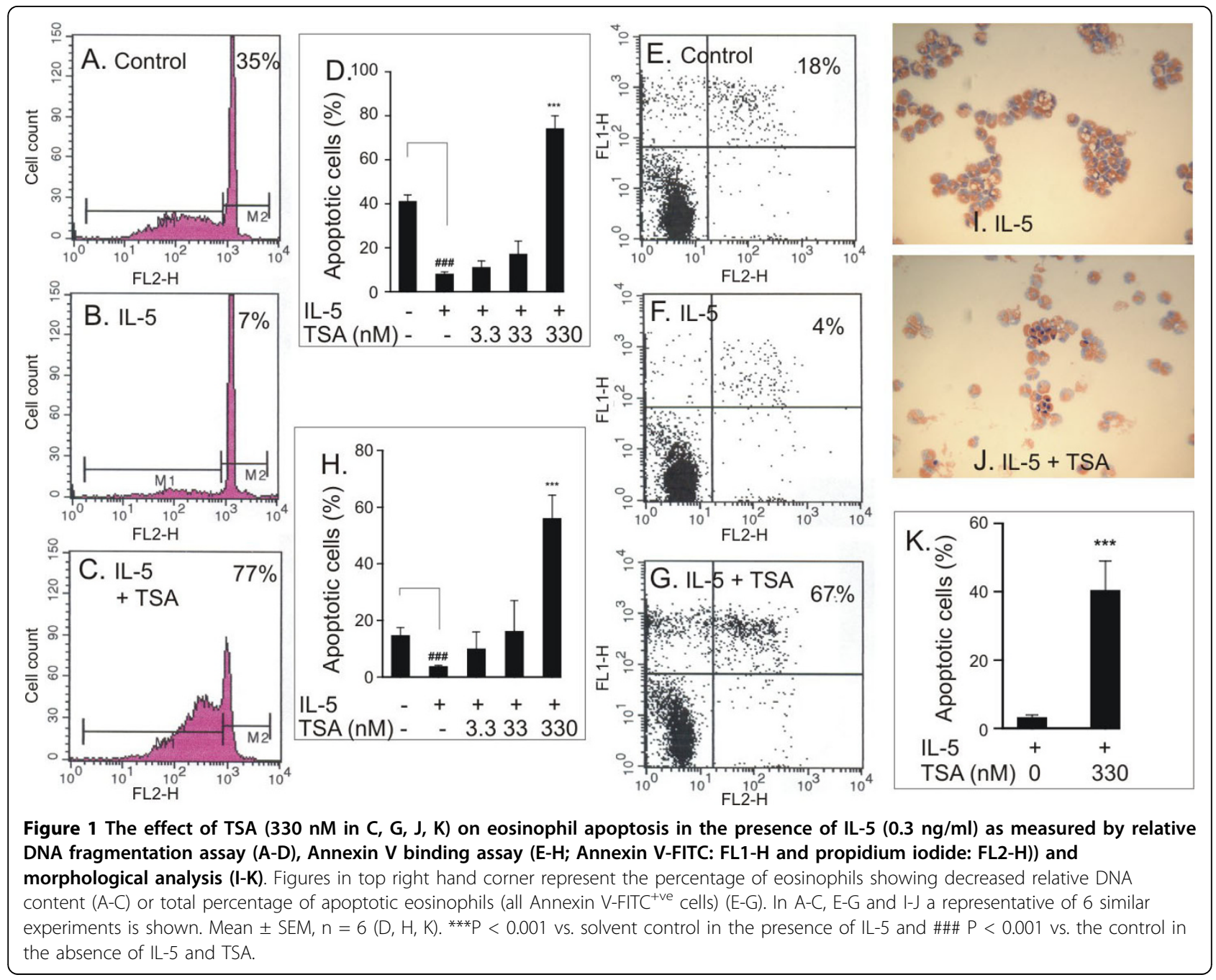




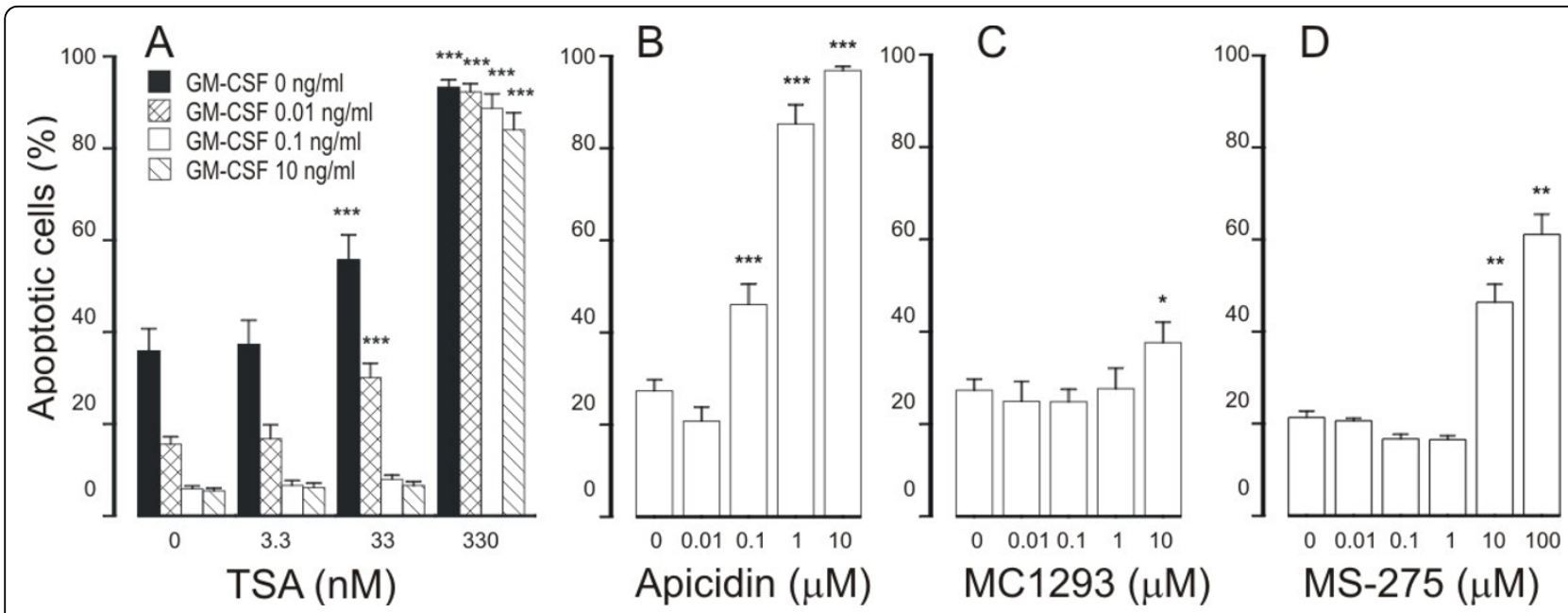

Figure 2 The effect of HDAC inhibitors Trichostatin A (TSA; A), apicidin (B), MC1293 (C) and MS-275 (D) on eosinophil apoptosis in the presence of GM-CSF (in B-D: $\mathbf{0 . 1} \mathbf{~ n g / m l ) . ~ I n ~ ( A ) ~ t h e ~ b l a c k ~ c o l u m s ~ i n d i c a t e ~ t h e ~ e f f e c t ~ o f ~ T S A ~ i n ~ t h e ~ a b s e n c e ~ o f ~ G M - C S F . ~ A p o p t o s i s ~ w a s ~ a s s e s s e d ~}$ by flow cytometry measuring the relative DNA fragmentation. ${ }^{* P}<0.05$, ${ }^{* *} \mathrm{P}<0.01$ and ${ }^{* * *} \mathrm{P}<0.001$ as compared with the respective control. Mean \pm S.E.M., $n=5-6$.

number of eosinophils showing the typical morphological features of apoptosis such as nuclear coalescense, chromatin condensation and cell shrinkage was found with TSA (Figure 1-K).

To evaluate whether the effect of TSA is specifically related to IL-5, we employed another eosinophil survival-prolonging cytokine, i.e. GM-CSF. GM-CSF (0.01 $10 \mathrm{ng} / \mathrm{ml}$ ) promoted eosinophil survival in a concentration-dependent manner (Figure 2A). TSA (3.3-330 nM) enhanced apoptosis in the presence of GM-CSF (0.01 $10 \mathrm{ng} / \mathrm{ml}$ ) (Figure 2A, Table 1).

Glucocorticoids are known to partially antagonize the survival-prolonging action of IL-5 or GM-CSF on eosinophils. However, this effect of glucocorticoids is abolished when the cytokine is used at higher concentrations [14,20-22]. For example, recently, we reported that budesonide $(1 \mu \mathrm{M})$ partly antagonizes cytokine-afforded survival in the presence of low but not in the presence of high concentrations of IL-5 [16]. The maximal response and the $\mathrm{EC}_{50}$ values (Table 1 ) of TSA were almost similar independently of the concentration of GM-CSF, suggesting that the cellular targets of TSA are different from that of glucocorticoids.

To evaluate whether the ability to antagonize cytokine-afforded eosinophil survival is not related to TSA only, we employed other pharmacological inhibitors of HDACs. Another general HDAC inhibitor, apicidin $(0.1-10 \mu \mathrm{M})$ antagonized GM-CSF-mediated eosinophil survival by inducing apoptosis with an $\mathrm{EC}_{50}$ of $427 \pm 42$ nM (Figure 2B). MC-1293, a commercially available HDAC1 inhibitor, antagonized GM-CSFmediated eosinophil survival only partially at high (10 $\mu \mathrm{M})$ drug concentrations (Figure 2C). Another HDAC inhibitor, MS-275 (0.1-1 $\mu \mathrm{M})$, at concentrations known to inhibit HDAC1 [23] did not affect GM-CSF-afforded eosinophil survival. In contrast, at higher concentrations (10-100 $\mu \mathrm{M})$ known to inhibit HDAC3 [23], MS275 enhanced apoptosis in GM-CSF-treated eosinophils (Figure 2D).

\section{HDAC inhibitors enhance constitutive eosinophil apoptosis}

In the absence of life-supporting cytokines, TSA increased the number of cells showing decreased relative DNA content suggesting apoptosis (Figure 2A, Table 1). Similarly, an increase in the number of cells presenting with the typical morphological features of apoptosis was found with TSA (percentage of apoptotic cells $11 \pm 3$ and $62 \pm 8$ in the absence and presence of $330 \mathrm{nM}$ TSA, respectively, $\mathrm{n}=5, \mathrm{P}<0.001)$. This was confirmed by showing an increase in the percentage of Annexin-Vpositive cells in the absence and presence of TSA (330 $\mathrm{nM})(15 \pm 3 \%$ and $68 \pm 8 \%$, respectively, $\mathrm{n}=6, \mathrm{P}<$ 0.001).

Apicidin enhanced spontaneous eosinophil apoptosis (Figure 3A). The selective HDAC1 inhibitor, MC1293, did not enhance eosinophil apoptosis (Figure 3B). MS275 (0.1-1 $\mu \mathrm{M})$ inhibited constitutive eosinophil apoptosis slightly, but at higher concentrations (10-100 $\mu \mathrm{M})$, known to inhibit HDAC3 [23], MS-275 enhanced constitutive eosinophil apoptosis (Figure 3C).

\section{HDAC inhibitors have additive effect on glucocorticoid- induced eosinophil apoptosis}

Glucocorticoids increase apoptosis of human eosinophils at clinically relevant drug concentrations $[3,14,20]$. 

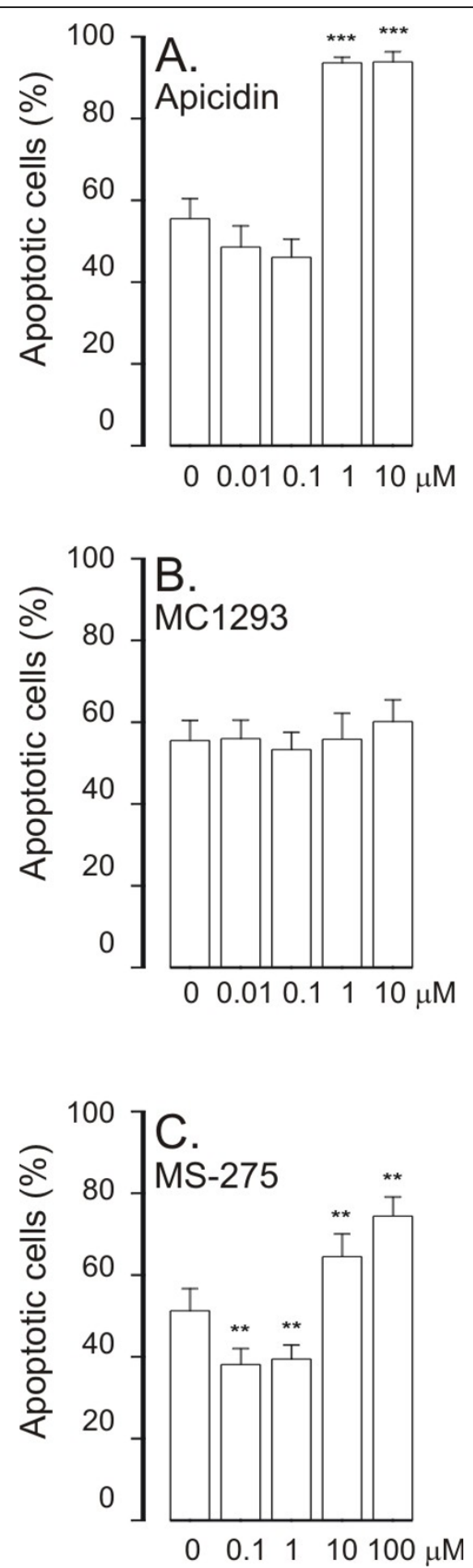

Figure 3 The effect of HDAC inhibitors apicidin (A), MC1293 (B) and MS-275 (C) on apoptosis in eosinophils in the absence of survival-prolonging cytokines (ie. spontaneous apoptosis). Apoptosis was assessed by flow cytometry measuring the relative DNA fragmentation in propidium iodide-stained cells. ${ }^{*} \mathrm{P}<0.01$ and ${ }^{* * *} P<0.001$ as compared with the respective control in the absence of HDAC inhibitors. Mean \pm S.E.M. of 5-6 independent determinations using cells from different donors.
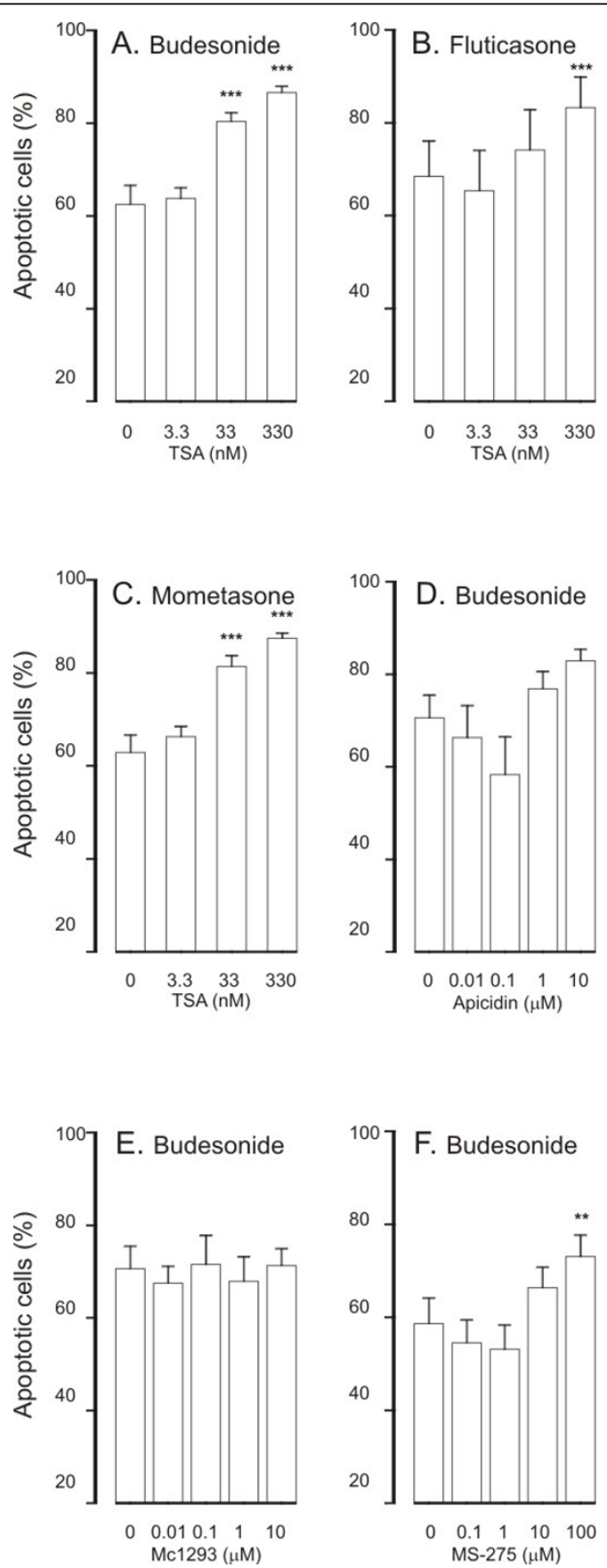

Figure 4 The effect of trichostatin $A(A-C)$ on human eosinophil apoptosis in the presence of budesonide $(1 \mu \mathrm{M} ; A)$, fluticasone $(1 \mu \mathrm{M} ; \mathrm{B})$ or mometasone $(1 \mu \mathrm{M} ; \mathrm{C})$. In (D-F) is shown the effects of HDAC inhibitors apicidin (D), MC1293 (E) and MS-275 (F) on eosinophil apoptosis in the presence of budesonide $(1 \mu \mathrm{M})$. Apoptosis was assessed by flow cytometry measuring the relative DNA fragmentation in propidium iodide-stained cells. ${ }^{* *}$ indicates $P<0.01$ and ${ }^{* * *} P<0.001$ as compared with the respective control in the absence of HDAC inhibitors. Mean \pm S.E.M. of 5-6 independent determinations using cells from different donors. The corresponding percentage of apoptotic cells in the absence of glucocorticoids and HDAC-inhibitors was $49 \pm 3(n=$ 25). 
Budesonide, fluticasone and mometasone (all at $1 \mu \mathrm{M}$ ) enhanced constitutive eosinophil apoptosis (Figure 4A-C and figure legend). A general HDAC inhibitor, TSA (3.3-330 $\mathrm{nM}$ ), had an additive effect in the presence of glucocorticoids (Figure 4A-C) on eosinophil apoptosis. The $\mathrm{EC}_{50}$ values of TSA for the enhancement of eosinophil apoptosis in the presence of glucocorticoids ranged from $20 \pm 5 \mathrm{nM}$ to $47 \pm 15 \mathrm{nM}$ (Table 1 ). The additive effect of TSA (3.3-330 nM) on budesonide-induced eosinophil apoptosis was confirmed by using morphological analysis and Annexin- $\mathrm{V}$ binding assay ( $\mathrm{n}=5-6, \mathrm{P}<$ 0.05; data not shown).

Apicidin (1 nM-10 $\mu \mathrm{M})$ also had an additive effect on budesonide-induced eosinophil apoptosis (Figure 4D). In contrast, MC-1293 (1 nM-10 $\mu \mathrm{M}$, Figure 4E) failed to enhance budesonide-enhanced eosinophil apoptosis. MS-275 at higher concentrations (10-100 $\mu \mathrm{M})$ had an additive effect on budesonide-induced eosinophil apoptosis (Figure 4F).

\section{HDAC-inhibitors have an additive effect on Fas-induced eosinophil apoptosis}

Activation of Fas enhanced constitutive apoptosis of eosinophils (percentage of apoptotic cells $47 \pm 4$ and 65 \pm 2 in the absence and presence of $100 \mathrm{ng} / \mathrm{ml}$ activating CD95 monoclonal antibody, respectively, $\mathrm{n}=6, \mathrm{P}<$ 0.01). TSA (3.3-330 nM) had an additive effect on Fasinduced eosinophils apoptosis (Table 1 and Table 2). This was confirmed by measuring the percentage of Annexin-V-positive cells in the absence and presence of TSA $(330 \mathrm{nM})(36 \pm 6 \%$ vs $74 \pm 8 \%, \mathrm{n}=6, \mathrm{P}<0.001)$. Furthermore, an increase in the number of eosinophils showing the typical morphological features of apoptosis was found with TSA (percentage of apoptotic cells $26 \pm$ 7 and $78 \pm 7$ in the absence and presence of $330 \mathrm{nM}$ TSA, respectively, $\mathrm{n}=6, \mathrm{P}<0.001$ ).

Table 2 The effects of trichostatin A on Fas-induced eosinophil apoptosis.

\begin{tabular}{ll}
\hline & Percentage of apoptotic cells \\
\hline Control & $47 \pm 4$ \\
Fas & $65 \pm 2 \# \#$ \\
Fas +trichostatin A $3.3 \mathrm{nM}$ & $67 \pm 3$ \\
Fas +trichostatin A $33 \mathrm{nM}$ & $79 \pm 2^{* * *}$ \\
Fas + trichostatin A $330 \mathrm{nM}$ & $89 \pm 1^{* * *}$
\end{tabular}

Shown is the percentage of apoptotic cells after $40 \mathrm{~h}$ incubation as analyzed by relative DNA fragmentation assay

Values are the mean \pm SEM of independent determinations using cells from different donors. $\mathrm{n}=6$. ${ }^{* * *}$ indicates $\mathrm{P}<0.001$ as compared with the respective solvent control in the absence of trichostatin $A$ and \#\# $\mathrm{P}<0.01$ as compared with the respective control in the absence of Fas. The concentration of Fas activating antibody was $100 \mathrm{ng} / \mathrm{ml}$.

\section{Effect of HDAC inhibitors on neutrophil apoptosis}

Neutrophils rapidly undergo apoptosis when cultured in the absence of survival-prolonging factors. GM-CSF inhibited constitutive apoptosis in neutrophils (percentage of apoptotic cells $60 \pm 5$ and $34 \pm 4$ in the absence and presence of $10 \mathrm{ng} / \mathrm{ml}$ GM-CSF, respectively, $\mathrm{n}=6$, $\mathrm{P}<0.001)$. TSA $(3.3-330 \mathrm{nM})$ antagonized the the survival promoting action of GM-CSF (Figure 5A) with an $E_{50}$ of $123 \pm 9 \mathrm{nM}$. The enhancement of neutrophil apoptosis by TSA in the presence of GM-CSF was confirmed by annexin- $\mathrm{V}$ binding analysis $(47 \pm 5 \%$ vs $60 \pm$ $8 \%, \mathrm{n}=4, \mathrm{P}<0.05)$. TSA also enhanced spontaneous neutrophil apoptosis 1.5 -fold (Figure $5 \mathrm{~B}$ ).

In contrast to the enhancing effect on eosinphil apoptosis, glucocorticoids inhibit apoptosis in human neutrophils $[13,14,24]$. For example, budesonide inhibited neutrophil apoptosis, the percentages of apoptotic cells were $60 \pm 5$ and $42 \pm 5$ in the absence and presence of budesonide $(1 \mu \mathrm{M})$, respectively $(\mathrm{n}=6, \mathrm{P}<0.001$, Figure $5 \mathrm{C})$. TSA (3.3-330 $\mathrm{nM}$ ) antagonized the inhibitory effect of budesonide (Figure $5 \mathrm{C}$ ) on neutrophil apoptosis. This was confirmed by Annexin- $\mathrm{V}$ binding analysis $(55 \pm 4 \%$ vs $91 \pm 1 \%$ Annexin V-positive cells, $\mathrm{n}=6, \mathrm{P}$ $<0.001)$. Furthermore, TSA antagonized fluticasone(Figure 5D) and mometasone- (Figure 5E)-induced survival of neutrophils by inducing apoptosis. The $\mathrm{EC}_{50}$ values of TSA for antagonizing glucocorticoid-afforded survival in neutrophils were not different between the glucocorticoids (Table 1).

\section{Pharmacological nature of the effect of HDAC inhibitors}

To further evaluate whether the effects of HDAC inhibitors on eosinophil and neutrophil apoptosis in the presence of glucocorticoids or Fas are additive or synergistic, dose-response curves of TSA in the absence or presence of survival-prolonging cytokines, glucocorticoids and Fas are compared (Figure 6A and 6B). In eosinophils, the maximal percentage of apoptotic cells is similar in the presence of TSA (330 nM) alone and in the presence of budesonide and TSA (330 nM) (Figure 6A). This indicates that the effect is additive, but not synergistic. The same can be seen with the combination of TSA and Fas. Similarly, in neutrophils, the maximal percentage of apoptotic cells is similar in the presence of TSA (330 nM) alone and in the presence of Fas and TSA (330 nM) (Figure 6B). In neutrophils, TSA enhanced apoptosis in the presence of GM-CSF and budesonide in a similar manner within the same concentration range (Figure 6B). Similarly, in eosinophils TSA enhanced apoptosis in the presence of IL-5 (Figure $6 \mathrm{~A})$. This suggests that the antagonism of the actions of survival-prolonging cytokines IL-5 and GM-CSF in both cell types and the antagonism of the actions of 


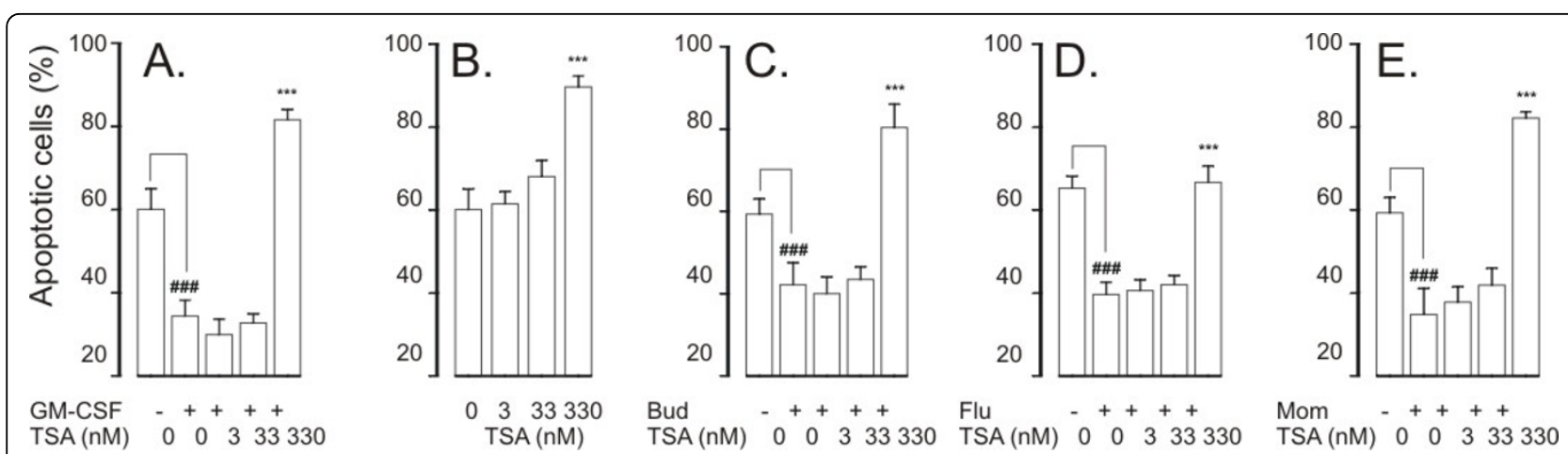

Figure 5 The effect of Trichostatin A on apoptosis in human neutrophils in the presence (A) or absence (B) of the survival-prolonging cytokine GM-CSF (10 $\mathbf{n g} / \mathbf{m l})$. In (C-E) is shown the effect of trichostatin A on human neutrophil apoptosis in the presence of budesonide (1 $\mu \mathrm{M} ; \mathrm{C})$, fluticasone $(1 \mu \mathrm{M} ; \mathrm{D})$ or mometasone $(1 \mu \mathrm{M} ; \mathrm{E})$. Apoptosis was assessed by flow cytometry measuring the relative DNA fragmentation assay. ${ }^{* * *} P<0.001$ as compared with the respective control in the absence of HDAC inhibitors. \#\#\# $P<0.001$ as compared with the respective control in the absence of HDAC inhibitors and GM-CSF or glucocorticoids. Mean \pm S.E.M. of 6 independent determinations using cells from different donors.

glucocorticoids does not occur at the level of IL-5, GMCSF or glucocorticoid receptors.

\section{HDAC expression in human eosinophils and neutrophils}

To evaluate whether granulocytes express HDACs, we isolated mRNA from human eosinophils and neutrophils and measured the expression of different HDACs using real-time PCR. To confirm the accuracy of the results, the expression of different HDACs was normalized against two different housekeeping genes, namely GAPDH and GLB2L1. This analysis gave almost identical results. Expression of HDAC5, 9 and 11 was very low in eosinophils and expression of HDAC5, 8 and 11 was very low in neutrophils (Figure 7). The expression of HDAC2 and HDAC9 was higher in neutrophils than in eosinophils and the expression of HDAC8 was significantly higher in eosinophils (Figure 7).

\section{HDAC activity in eosinophils and neutrophils}

The HDAC activity in eosinophil nuclear extracts was somewhat higher $(0.37 \pm 0.05 \mathrm{OD} / \mathrm{mg} / \mathrm{min} ; \mathrm{n}=6)$ than in neutrophil nuclear extracts $(0.22 \pm 0.05 \mathrm{OD} / \mathrm{mg} / \mathrm{min}$; $\mathrm{n}=5, \mathrm{P}<0.05)$. For comparison, we included HeLacell nuclear extracts which had clearly higher HDAC activity $(0.70 \pm 0.04 \mathrm{OD} / \mathrm{mg} / \mathrm{min}, \mathrm{n}=6, \mathrm{P}<0.001$ versus eosinophil and neutrophil nuclear extracts). TSA inhibited substrate $(1.25 \mathrm{mM})$ deacetylation by eosinophil and neutrophil nuclear extracts only partially. The maximal inhibition of HDAC activity by TSA (1000 $\mathrm{nM})$ in eosinophil nuclear extracts was $59 \pm 13 \%$ ( $\mathrm{n}=$ $6, \mathrm{P}<0.05)$ and in neutrophil nuclear extracts it was 50 $\pm 4 \%(\mathrm{n}=5, \mathrm{P}<0.001)$, whereas in HeLa nuclear extracts HDAC activity was inhibited almost completely (93 $\pm 1 \%$ inhibition, $\mathrm{n}=6, \mathrm{P}<0.001$ ) by $1000 \mathrm{nM}$ TSA (Figure 8).
Acetylation of NF- $\kappa$ B p65 does not explain the apoptosisinducing effect of TSA in human eosinophils

The above data suggest that the effects of HDAC inhibitors in eosinophils or neutrophils may not be mediated via regulation of acetylation status of histones, but rather might be mediated via some non-histone targets. $\mathrm{NF}-\kappa \mathrm{B}$ has been shown to be involved in the regulation of eosinophil apoptosis [3]. NF- $\kappa \mathrm{B}$ assembly with $\mathrm{I} \kappa \mathrm{B}$, as

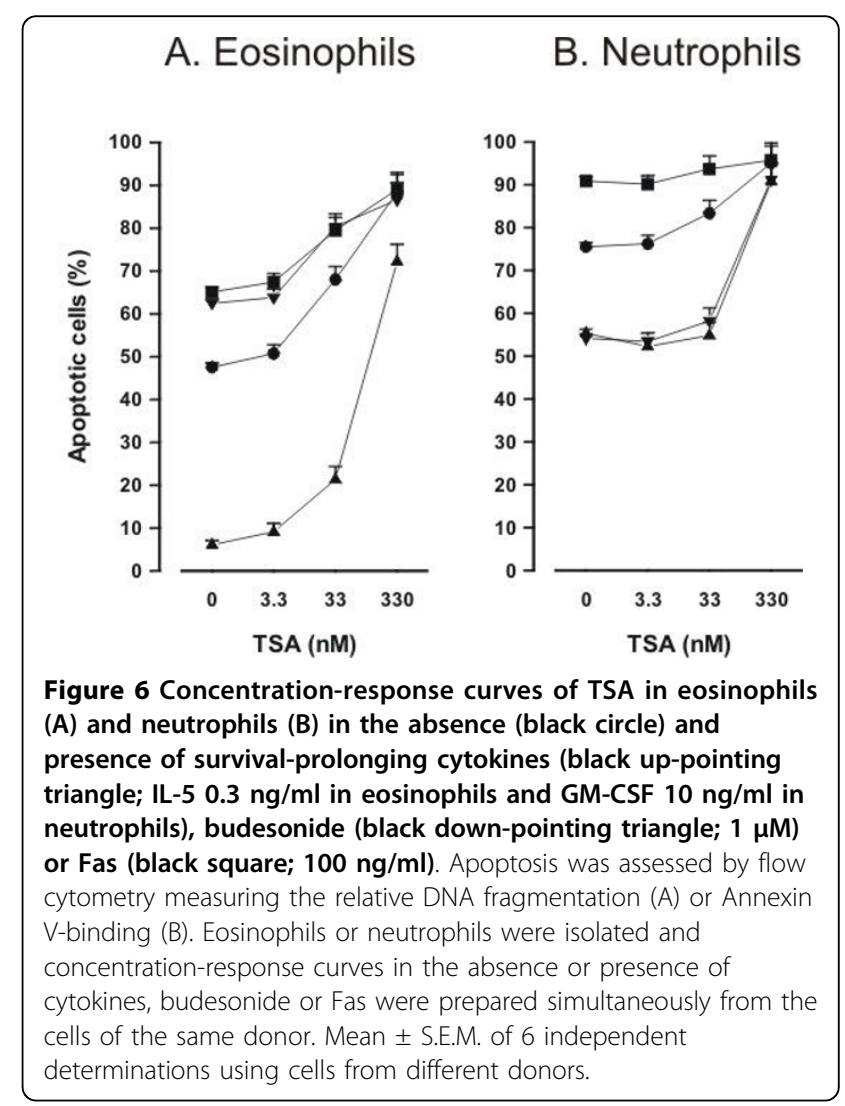




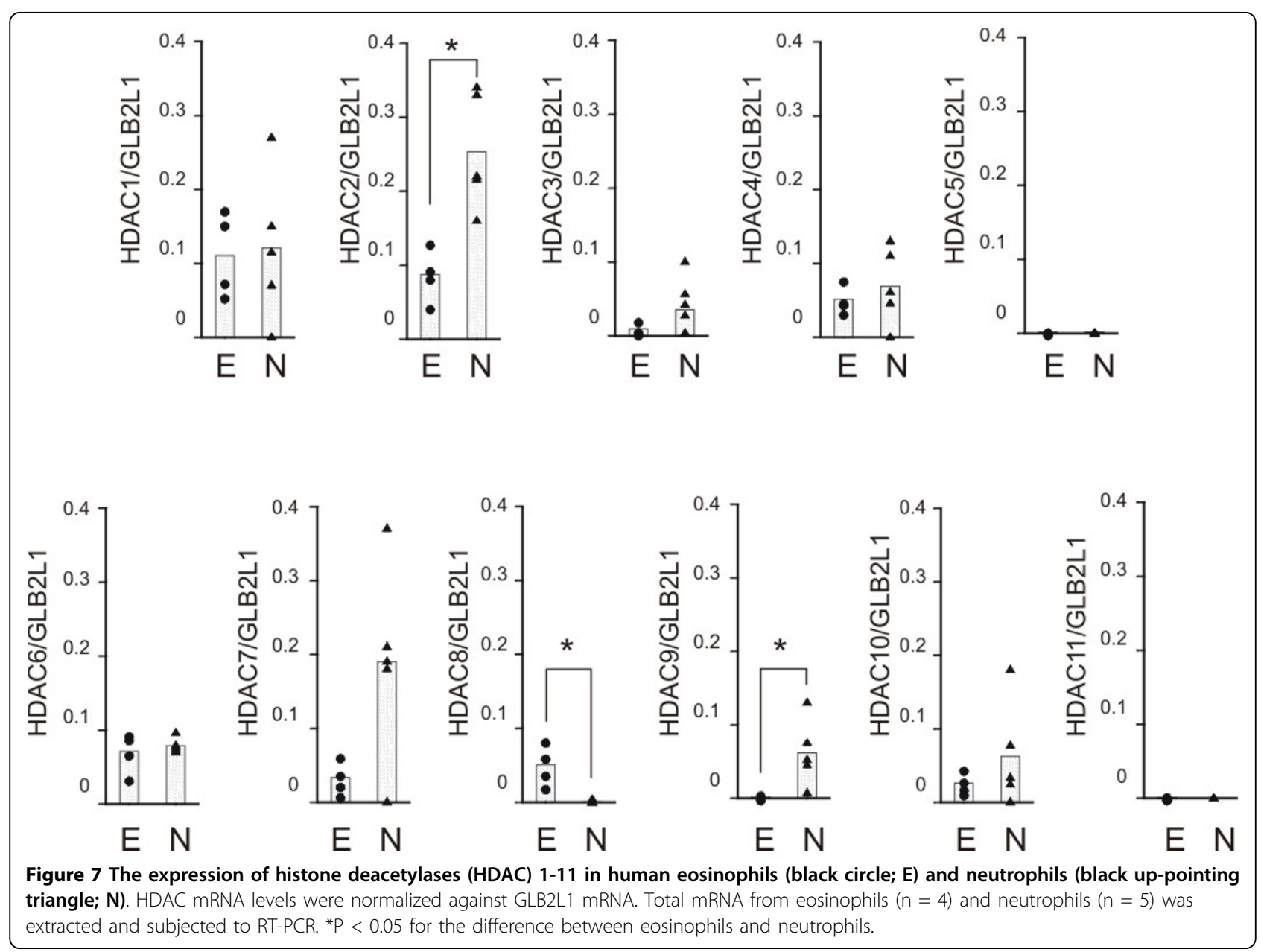

well as its DNA binding and transcriptional activity, are regulated by $\mathrm{p} 300 / \mathrm{CBP}$ acetyltransferases that principally target Lys218, Lys221 and Lys310 [25-27]. This process is reciprocally regulated by HDACs and several HDAC inhibitors have been shown to activate NF- $\kappa \mathrm{B}$ [25-27]. To evaluate whether the effects of HDAC inhibitors could be mediated via acetylation of a non-histone target such as NF- $\kappa \mathrm{B}$, we evaluated the effect of TSA on the acetylation status of NF- $\kappa \mathrm{B}$ p65. However, TSA (330 $\mathrm{nM}$ ) did not enhance acetyl-p65 expression in human eosinophils either in the absence $(n=5$; Figure 9$)$ or presence of GM-CSF $(n=2)$ (data not shown).

\section{Effect of c-jun-N-terminal kinase and PI3K-Akt pathway inhibitors on TSA-induced apoptosis in human eosinophils}

c-jun-N-terminal kinase (JNK) and PI3K-Akt pathways have been proposed to be involved in the modulation of human eosinophil longevity [3,28,29]. To test the involvement of these pathways in HDAC-inhibitor-induced apoptosis, we employd pharmacological inhibitors of JNK and PI3K. Inhibition of JNK activity by the cell permeable inhibitory peptide L-JNKI1 almost completely abolished TSA (330 nM)-enhanced DNA breakdown. In contrast, the negative control peptide L-TAT had no effect (Figure 10).

Inhibition of PI3K-Akt pathway by two chemically distinct inhibitors, namely wortmannin (10-100 nM) and LY294002 (5-50 $\mu \mathrm{M})$ did not affect TSA-induced apoptosis in human eosinophils ( $n=6$, data not shown).

\section{Involvement of caspases in TSA-induced apoptosis in human eosinophils}

Even though the involvement of caspases in apoptosis in general is well established, surprisingly little is known of the role caspases in human eosinophils $[3,30]$ and the actual caspases mediating apoptosis in human eosinophils remain largely unknown [3,30]. General caspase inhibitors Q-Vd-OPh and Z-Asp-CH2-DCB completely antagonized the effect of TSA on apoptosis in human eosinophils (Figure 11). Inhibitors of caspase 6 (Z-VE (OMe)ID(OMe)-FMK) and 3 (Z-D(OMe)QMD(OMe)FMK) compeletely and partly antagonized TSA-induced DNA breakdown in human eosinophils, respectively 


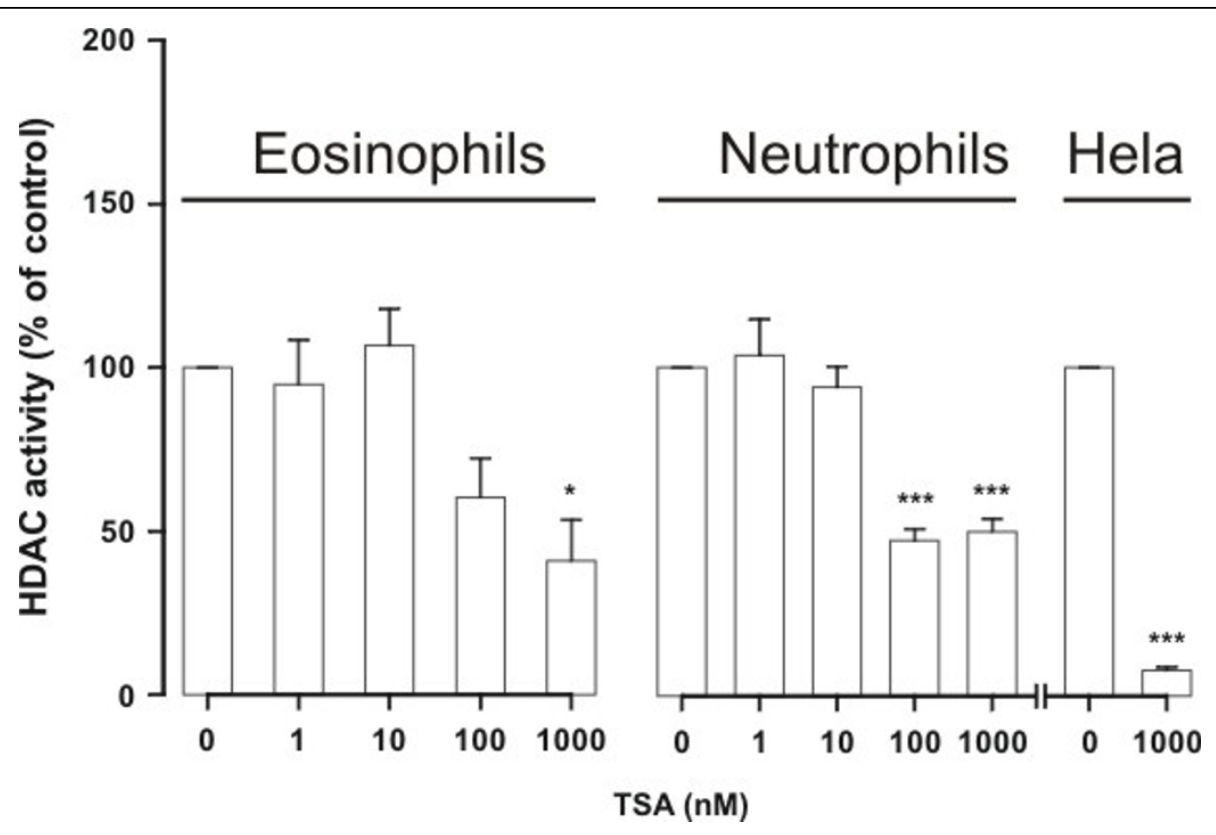

Figure 8 The effect of HDAC inhibitor Trichostatin A (TSA) on HDAC activity in nuclear extracts isolated from human eosinophils $(\mathrm{n}=$ 6) and neutrophils $(\mathbf{n}=\mathbf{5})$. For comparison is shown the effect of TSA on HDAC activity in HeLa nuclear extracts $(n=6)$. Nuclear extracts were prepared and HDAC activity was measured as described in materials and methods. HDAC activity in the absence of TSA was set as $100 \%$. ${ }^{*} \mathrm{P}<$ 0.05 and ${ }^{* *} P<0.001$ as compared with the respective control in the absence of TSA. Mean \pm S.E.M.
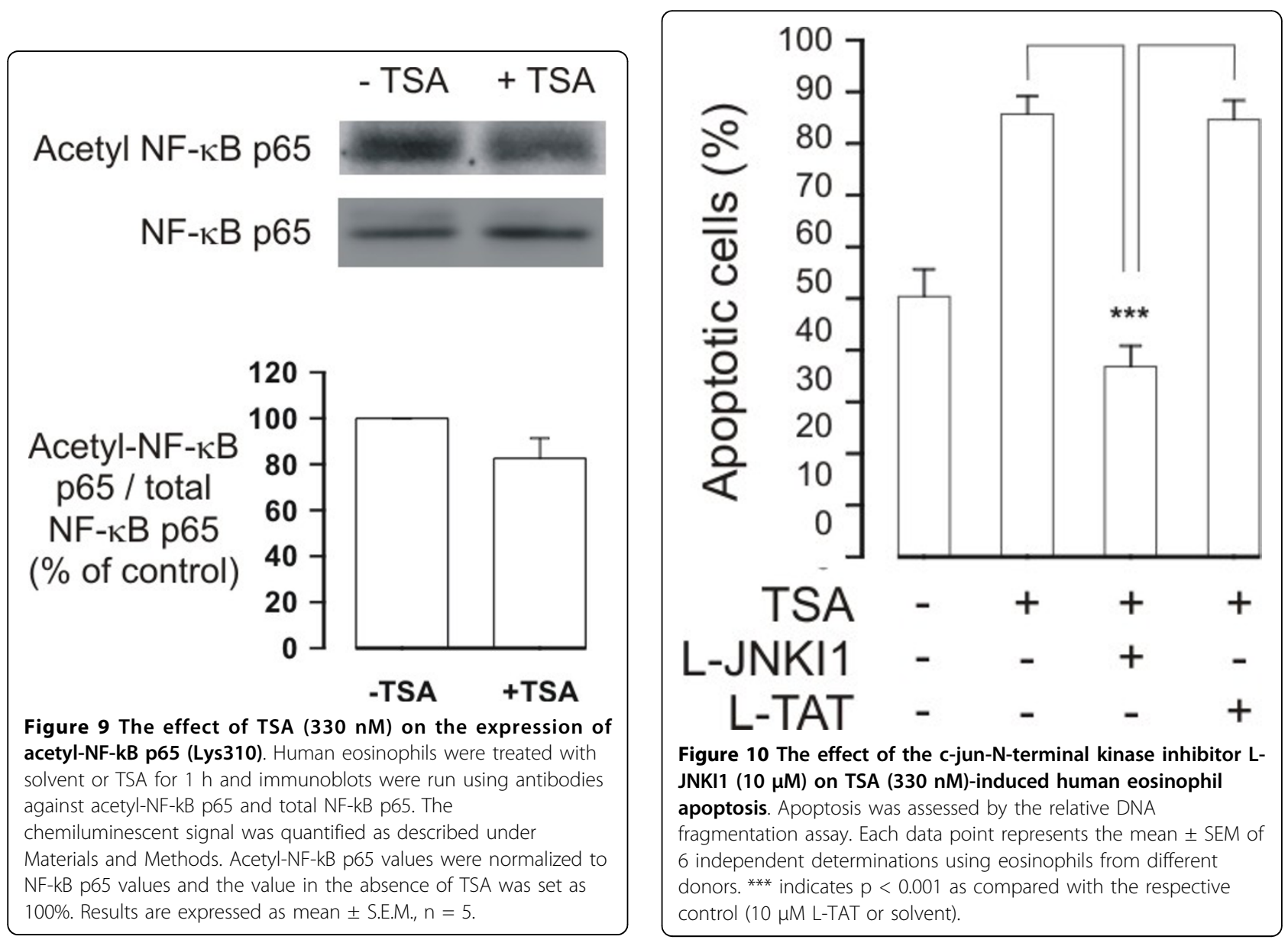


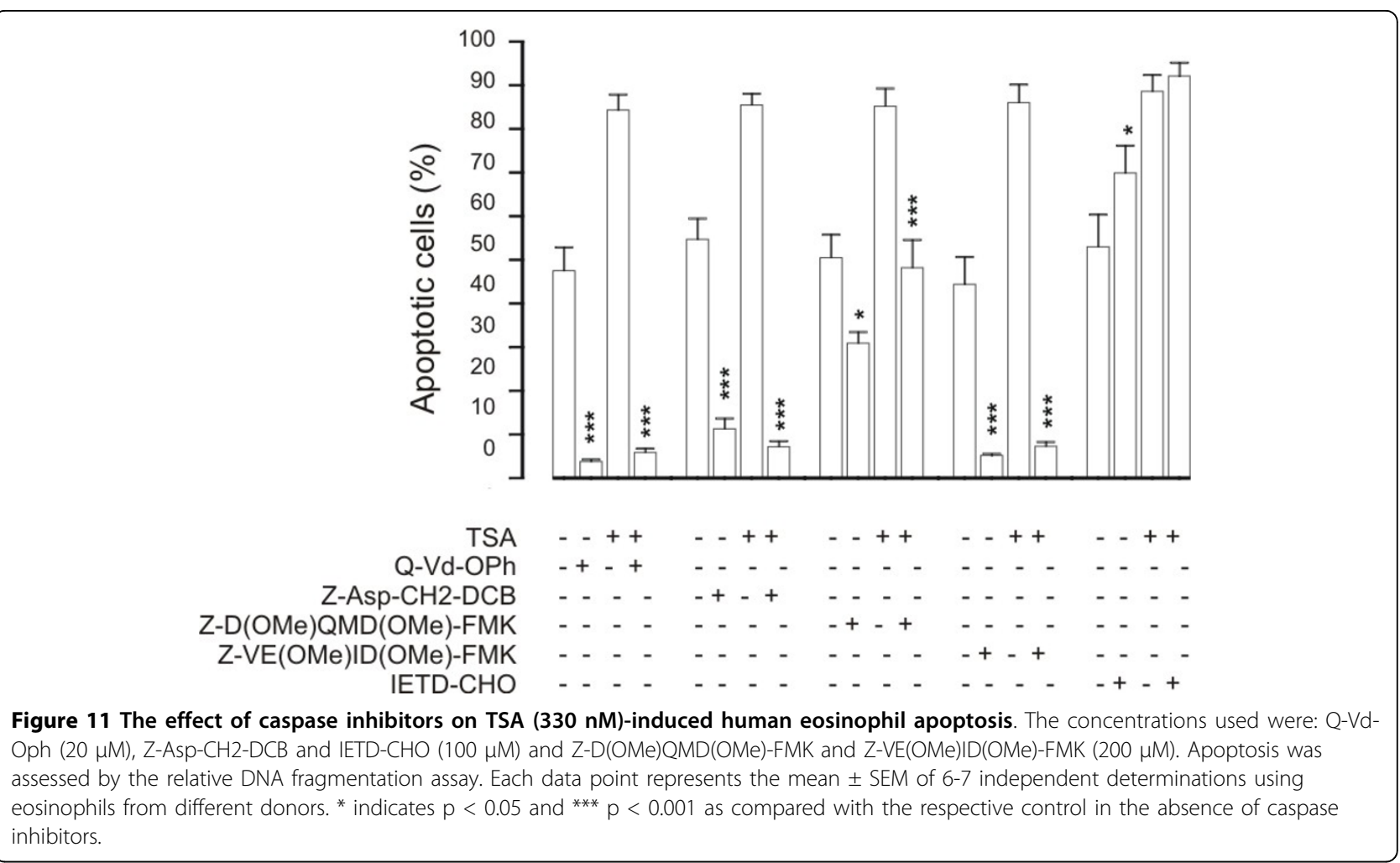

(Figure 11). In contrast, inhibition of caspase 8 (IETD$\mathrm{CHO}$ ) had no effect (Figure 11). These results suggest a role for caspases 3 and 6 , but not 8 , in the mechanism of action of TSA in human eosinophils.

\section{HDAC inhibitors enhance apoptosis in $\mathbf{J 7 4}$ macrophages}

Macrophages are considered to be important in the removal of apoptotic cells. To evaluate whether HDAC inhibitors could affect macrophage survival, we evaluated the effects of TSA on apoptosis in J774.2 macrophages. TSA increased the percentage of Annexin Vpositive cells in J774.2 macrophages in a concentrationdependent manner, although to a lesser extent than a combination of LPS and an inhibitor of NF- $\kappa$ B PDTC $(100 \mu \mathrm{M})$, previously known to induce apoptosis in macrophages (Figure 12).

\section{Discussion}

In the present study we show that HDAC inhibitors inhibit HDAC acitivity and induce apoptosis in human eosinophils and neutrophils in the absence and presence of survival-prolonging cytokines and glucocorticoids. Furthermore, we report that eosinophils and neutrophils express a different pattern of HDACs, namely the expression of HDAC2 and HDAC9 is higher in neutrophils than in eosinophils and the expression of HDAC8

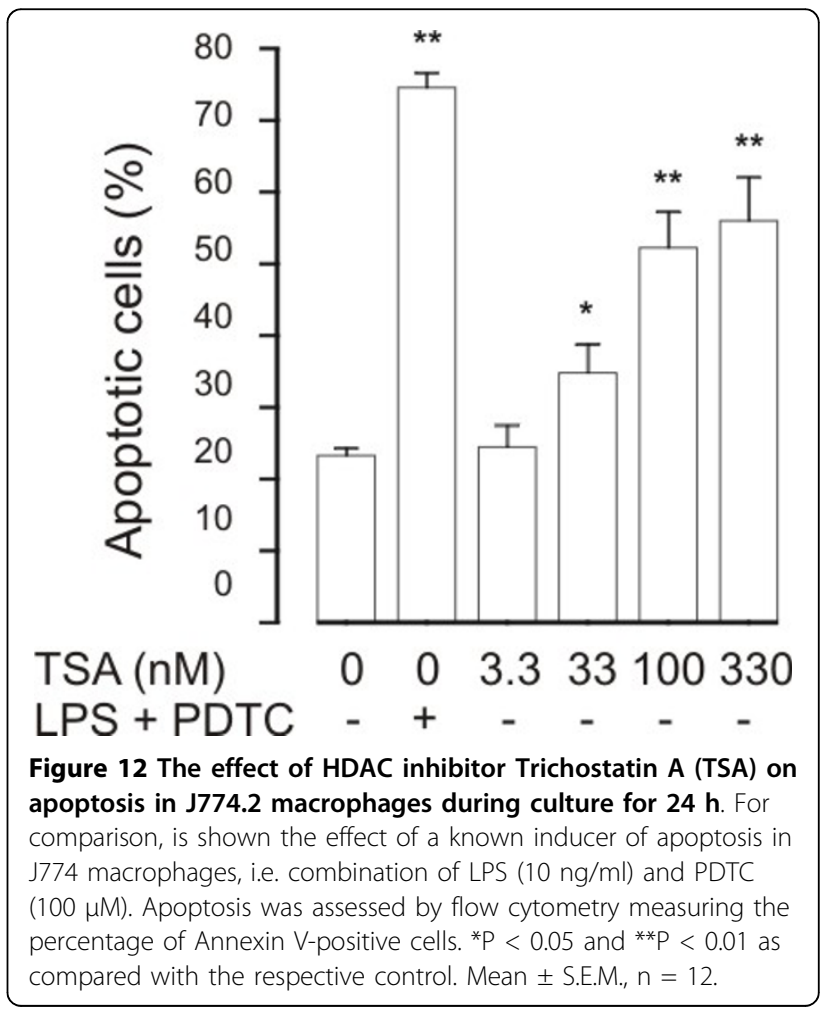


is higher in eosinophils than in neutrophils. The mechanism of apoptosis-enhancing action of HDAC inhibitors in human eosinophils seems to involve JNK and caspases 3 and 6 .

HDAC inhibitors have been reported to cause apoptotic cell death in a variety of cultured transformed cells, including human bladder, breast, prostate, lung, ovary and colon cancers and acute myelogenous leukemia [31]. For example, HDAC inhibitors such as apicidin, sodium butyrate, suberoylanilide hydroxamic acid (SAHA) and TSA have been reported to reduce viability or induce apoptosis in HeLa cells [32,33]. In contrast, normal cells are usually resistant to cell death caused by HDAC inhibitors $[9,10]$ and there is no previous data to describe the effects of HDAC inhibitors on apoptosis in human eosinophils or neutrophils. Supporting our results on the possible anti-inflammatory effects of HDAC inhibitors on granulocytes, recent in vivo data in animals suggest that HDAC inhibitors may have potential to act as anti-inflammatory agents. Choi and coworkers [12] demonstrated that TSA given prophylactically blocked OVA-induced airway hyper-responsiveness, as well as reduced the numbers of eosinophils in lavage fluid [12]. Interestingly, HDAC inhibitors seem not to block the production of eosinophil life-supporting cytokines such as IL-5, but rather may enhance the activity of IL-5 promoter [34]. Thus, it is tempting to speculate that as HDAC inhibitors may not reduce the concentrations of eosinophil survival-prolonging cytokines. The finding that TSA enhances apoptosis in the presence of IL-5- and GM-CSF, may, at least partly, explain the beneficial effects of TSA in models of eosinophilic inflammation.

Structurally distinct HDAC inhibitors were used. Unfortunately, the inhibitory profiles of HDAC inhibitors against all HDAC isoforms have not been thoroughly characterized. TSA has been reported to be a general HDAC inhibitor [31,35-37]. HDAC1 selective inhibitors, MC-1293 [38] and MS-275 at low concentrations [23] did not affect eosinophil apoptosis to a similar extent than TSA or apicidin. This probably excludes HDAC1 as a target of HDAC inhibitors. However, given that the effect of TSA in the HDAC activity assay experiments using nuclear extracts obtained from eosinophils or neutrophils revealed that the HDAC activity was reduced only by $50-60 \%$ even at $1 \mu \mathrm{M}$ suggests either that granulocytes possess a TSA-insensitive HDAC e.g. HDAC4 or 7 or that HDACs are not the major target for HDAC inhibitors in these cells. The $\mathrm{EC}_{50}$ values for TSA in enhancing apoptosis in the presence or absence of glucocorticoids were different between eosinophils and neutrophils, whereas no difference was found in the $\mathrm{EC}_{50}$ values for TSA in the presence of GM-CSF. This suggests that there may be two or more HDACs responsible mediating these effects or that the effect may reflect the combined effect of two or more HDACs. The expression of HDAC2, HDAC8 and HDAC9 were different between eosinophils and neutrophils. This suggests that one or more of these HDACs may also be involved.

In malignant cell lines activation of caspase cascades as well as changes in the expression of Bcl-2 family members have been described $[9,10]$. The exact mechanisms how the survival-prolonging cytokines IL-5 and GM-CSF induce eosinophil survival or glucocorticoids induce eosinophil death are not known in detail $[3,22,30]$. In fact, it is not even known whether glucocorticoid-induced apoptosis involves mainly transcriptional activation or repression [39]. Mechanistically, inhibition of HDAC activity should lead to increased transcription. Treatment with HDAC inhibitors in an in vitro situation leads almost up to $10 \%$ of transcriptionally active genes having altered expression [9]. Surprisingly, nearly an equal number of genes are repressed in their expression as those that are activated [9]. Treatment with HDAC inhibitors in vitro causes an increase in the acetylation levels of histones in both normal and tumor cells, including melanocytes and melanoma cell lines [9]. However, normal melanocytes are resistant to cell death caused by HDAC inhibitors, whereas most melanoma cell lines undergo apoptosis [9]. This suggests that the difference between survival and death between normal and malignant cells may be due to acetylation of non-histone proteins rather than histones themselves $[9,10]$. In eosinophils, NF- $\kappa \mathrm{B}$ has been shown to be involved in the regulation of apoptosis [3]. NF- $\kappa \mathrm{B}$ assembly with $\mathrm{I} \kappa \mathrm{B}$, as well as its DNA binding and transcriptional activity, are regulated by p300/CBP acetyltransferases that principally target Lys218, Lys 221 and Lys310 [25-27]. This process is reciprocally regulated by HDACs and several HDAC inhibitors have been shown to activate NF- $\kappa B$ [25-27]. In fact, ineffectiveness of HDAC inhibitors to induce apoptosis in certain cell lines has been proposed to involve the transcriptional activation by acetylation of RelA/p65 subunit of NF-kB through the Akt pathway [26]. However, we were not able to detect any increased acetylation of NF-kB p65 in response to TSA in human eosinophils. Similarly, inhibition of the PI3K-Akt pathway by pharmacological inhibitors did not modulate TSA-induced apoptosis. These results suggest that NF-kB p65 or PI3K-Akt pathway are not involved, but we cannot exclude other non-histone targets.

c-jun-N-terminal kinase (JNK) pathway has been proposed to be involved in spontaneous and nitric oxideand orazipone-induced apoptosis of human eosinophils $[3,16,17,28]$. Inhibition of JNK activity by the cell permeable inhibitory peptide L-JNKI1 almost completely 
abolished TSA-enhanced DNA breakdown, suggesting a role for JNK. Even though the involvement of caspases in apoptosis in general is well established, surprisingly little is known of the role caspases in human eosinophils $[3,30]$ and the actual caspases mediating apoptosis in human eosinophils remain largely unknown $[3,30]$. General caspase inhibitors Q-Vd-OPh and Z-Asp-CH2-DCB completely antagonized the effect of TSA on apoptosis in human eosinophils similarly to inhibitors of caspases 6 and 3, whereas inhibition of caspase 8 had no effect. However, caspase inhibition also reduced spontaneous apoptosis as previously described [16]. These results suggest a role for JNK and caspases 3 and 6 , but not 8 , in the mechanism of action of TSA in human eosinophils. This interpretation may be complicated by the fact that the specificity of these inhibitors for caspases 3 , 6 and 8 has not been completely characterized. However, neither JNK nor caspases 3 and 6 appear specific for HDAC-inhibitor-induced apoptosis as they have been reported to affect spontaneous or induced apoptosis in human eosinophils $[3,16,17,28]$.

In contrast to the potentiation of glucocorticoid effects in eosinophils, in neutrophils TSA antagonized the survival-prolonging effect of glucocorticoids on neutrophil survival. In addition, the $\mathrm{EC}_{50}$ value for TSA for antagonism of glucocorticoid-induced survival in neutrophils was higher than that in eosinophils for enhancement of glucocorticoid-induced apoptosis. One might argue that the effect of HDAC inhibitors is non-specific in that they override the effects of any survival-prolonging factor in granulocytes.

Accumulation, activation and delayed death of neutrophils at the inflamed site has recently been implicated in the pathogenesis of COPD, severe asthma and asthma exacerbations [1]. We found that TSA antagonized GMCSF-afforded neutrophil survival by inducing apoptosis. In addition, TSA enhanced apoptosis in the absence and presence of glucocorticoids in neutrophils. We were not able to identify any studies exploring the effects of TSA on neutrophilic inflammation in the lung and based on our results such studies are warranted.

HDAC inhibitors are unique in the sense that they antagonize cytokine-afforded survival of eosinophils and neutrophils despite the vast amount of literature that indicates that they are not toxic towards several types of normal non-malignant cell lines $[9,10]$. In fact, the published phase I-II clinical trials suggest that HDAC inhibitors: 1. inhibit HDAC activity in vivo in humans and 2. show moderate to good tolerability in humans [40-44]. Thus, it is tempting to speculate that HDAC inhibitors might be used to treat also eosinophilic and/ or neutrophilic inflammation.

Macrophages are considered to be important in the removal of apoptotic cells. The finding that TSA at similar concentrations induced apoptosis also in a macrophage cell-line suggests that removal of apoptotic cells in the lungs could be impaired. However, in addition to macrophages, lung epithelial cells have been implicated in the removal of apoptotic eosinophils [45] and A549 lung epithelial cells have been reported to be insensitive to apoptosis induced by HDAC inhibitors [26].

\section{Conclusions}

Taken together, our results suggest that HDAC inhibitors such as TSA enhance apoptosis both in the presence and absence of survival-prolonging cytokines in eosinophils and neutrophils. In addition, TSA has an additive effect on apoptosis in the presence of glucocorticoids in eosinophils and antagonizes glucocorticoidinduced neutrophil survival. The mechanism of action in eosinophils involves c-jun- $\mathrm{N}$-terminal kinase and caspases 3 and 6 . Thus, HDAC inhibitors have anti-eosinophilic and anti-neutrophilic properties and are possible drug candidates to treat eosinophilic or neutrophilic inflammation.

\section{List of abbreviations}

(COPD): Chronic obstructive pulmonary disease; (GMCSF): Granulocyte-macrophage colony-stimulating factor; (HAT): Histone acetyltransferase; (HDAC): Histone deacetylase; (IL): Interleukin; (L-JNKI1): GRKKRRQRRR-PP-RPKRPTTLNLFPQVPRSQD-amide; (LPS): Lipopolysaccharide; (L-TAT): RKKRRQRRRamide, negative control for L-JNKI1; (MC1293): 3-(4toluoyl-1-methyl-1H-2-pyrrolyl)-N-hydroxy-2-propenamide; (MS-275): [N-(2-aminophenyl)-4-[N-(pyridine-3ylmethoxy-carbonyl)aminomethyl]benzamide]; (PDTC): ammonium pyrrolidinedithiocarbamate; (TSA): Trichostatin A.

\section{Acknowledgements}

Supported by Tampere Tuberculosis Foundation (Finland), the Academy of Finland, the Finnish Anti-Tuberculosis Association Foundation (Finland), and the Medical Research Funds of Tampere University Hospital (Finland) and Seinäjoki Central Hospital (Finland). The skilful technical help of Ms. Elina Heiskanen is gratefully acknowledged.

\section{Author details}

'The Immunopharmacology Research Group, Medical School, FIN-33014, University of Tampere and Research Unit, Tampere University Hospital, Tampere, Finland. ${ }^{2}$ Department of Respiratory Medicine, Seinäjoki Central Hospital, Seinäjoki, Finland. ${ }^{3}$ Airway Disease, Imperial College School of Medicine at the National Heart and Lung Institute, London, UK.

\section{Authors' contributions}

HK, MJ-J, PI and XZ carried out the eosinophil and neutrophil isolation, flow cytometric assays, morphological analyses, HDAC assays and western blot analysis. UJ gave valuable collaboration in laboratory studies. KI and MI performed the HDAC mRNA assays. Kl, IMA and EM participated in the design of the study and helped to draft the manuscript. HK conceived the 
study, and participated in its design and coordination and drafted the manuscript with XZ. All authors read and approved the final manuscript.

\section{Competing interests}

The authors declare that they have no competing interests.

Received: 8 April 2009

Accepted: 4 February 2010 Published: 4 February 2010

\section{References}

1. Watt AP, Schock BC, Ennis M: Neutrophils and eosinophils: clinical implications of their appearance, presence and disappearance in asthma and COPD. Curr Drug Targets-Inflammation Allergy 2005, 4:415-423.

2. Walker A, Ward C, Taylor EL, Dransfield I, Hart SP, Haslett C, Rossi AG: Regulation of neutrophil apoptosis and removal of apoptotic cells. Curr Drug Targets-Inflammation Allergy 2005, 4:447-454.

3. Kankaanranta H, Moilanen E, Zhang X: Pharmacological regulation of human eosinophil apoptosis. Curr Drug Targets-Inflammation Allergy 2005, 4:433-445.

4. Wedi B, Raap U, Lewrick H, Kapp A: Delayed eosinophil programmed cell death in vitro: a common feature of inhalant allergy and extrinsic and intrinsic atopic dermatitis. J Allergy Clin Immunol 1997, 100:536-43.

5. Kankaanranta H, Lindsay MA, Giembycz MA, Zhang X, Moilanen E, Barnes PJ: Delayed eosinophil apoptosis in asthma. J Allergy Clin Immunol 2000, 106:77-83

6. Vignola AM, Chanez P, Chiappara G, Siena L, Merendino A, Reina C Evaluation of apoptosis of eosinophils, macrophages, and T lymphocytes in mucosal biopsy specimens of patients with asthma and chronic bronchitis. J Allergy Clin Immunol 1999, 103:563-73.

7. Adcock IM: Histone deacetylase inhibitors as novel anti-inflammatory agents. Curr Opin Invest Drugs 2006, 7:966-73.

8. Barnes PJ: How corticosteroids control inflammation: Quintiles Prize Lecture 2005. Br J Pharmacol 2006, 148:245-54.

9. Boyle GM, Martyn AC, Parsons PG: Histone deacetylase inhibitors and malignant melanoma. Pigment Cell Res 2005, 18:160-6.

10. Dokmanovic M, Marks PA: Prospects: histone deacetylase inhibitors. J Cell Biochem 2005, 96:293-304.

11. Chung YL, Lee MY, Wang AJ, Yao LF: A therapeutic strategy uses histone deacetylase inhibitors to modulate the expression of genes involved in the pathogenesis of rheumatoid arthritis. Mol Ther 2003, 8:707-17.

12. Choi JH, Oh SW, Kang MS, Kwon HJ, Oh GT, Kim DY: Trichostatin A attenuates airway inflammation in mouse asthma model. Clin Exp Allergy 2005, 35:89-96.

13. Zhang X, Moilanen E, Kankaanranta H: Beclomethasone, budesonide and fluticasone propionate inhibit human neutrophil apoptosis. Eur $J$ Pharmacol 2001, 431:365-371.

14. Zhang X, Moilanen E, Adcock IM, Lindsay MA, Kankaanranta H: Divergent effect of mometasone on human eosinophil and neutrophil apoptosis. Life Sci 2002, 71:1523-1534.

15. Kankaanranta H, De Souza PM, Barnes PJ, Salmon M, Giembycz MA, Lindsay MA: SB 203580, an inhibitor of p38 mitogen-activated protein kinase, enhances constitutive apoptosis of cytokine-deprived human eosinophils. J Pharm Exp Ther 1999, 290:621-628.

16. Kankaanranta $H$, Ilmarinen $P$, Zhang $X$, Nissinen $E$, Moilanen $E$ : Antieosinophilic activity of orazipone. Mol Pharmacol 2006, 96:1861-70.

17. Zhang X, Moilanen E, Lahti A, Hämäläinen M, Giembycz MA, Barnes PJ, Lindsay MA, Kankaanranta $\mathrm{H}$ : Regulation of eosinophil apoptosis by nitric oxide: Role of c-Jun-N-terminal kinase and signal transducer and activator of transcription 5. J Allergy Clin Immunol 2003, 112:93-101.

18. Dignam JD, Lebovitz RM, Roeder RG: Accurate transcription initiation by RNA polymerase II in a soluble extract from isolated mammalian nuclei. Nucleic Acids Res 1983, 11:1475-1489.

19. Lahti $\mathrm{A}$, Jalonen $\mathrm{U}$, Kankaanranta $\mathrm{H}$, Moilanen $\mathrm{E}$ : c-Jun $\mathrm{NH}_{2}$-Terminal Kinase Inhibitor anthra(1,9-cd)pyrazol-6(2H)-one Reduces Inducible Nitric-Oxide Synthase Expression by Destabilizing mRNA in Activated Macrophages. Mol Pharmacol 2003, 64:308-315.

20. Zhang $\mathrm{X}$, Moilanen $\mathrm{E}$, Kankaanranta $\mathrm{H}$ : Enhancement of human eosinophil apoptosis by fluticasone propionate, budesonide, and beclomethasone. Eur J Pharmacol 2000, 406:325-332.
21. Hagan JB, Kita H, Gleich GJ: Inhibition of interleukin-5 mediated eosinophil viability by fluticasone 17-propionate: comparison with other glucocorticoids. Clin Exp Allergy 1998, 28:999-1006.

22. Druilhe A, Letuve S, Pretolani M: Glucocorticoid-induced apoptosis in human eosinophils: mechanisms of action. Apoptosis 2003, 8:481-495.

23. Hu E, Dul E, Sung C-M, Chen Z, Kirkpatrick R, Zhang G-F, Johanson K, Liu R, Lago A, Hofmann G, Macarron R, de los Frailes M, Perez P, Krawiec J, Winkler J, Jaye M: Identification of novel isoform-selective inhibitors within class I histone deacetylases. J Pharm Exp Ther 2003, 307:720-728.

24. Meagher LC, Cousin JM, Seckl JR, Haslett C: Opposing effects of glucocorticoids on the rate of apoptosis in neutrophilic and eosinophilic granulocytes. J Immunol 1996, 156:4422-4428.

25. Ashburner BP, Westerheide SD, Baldwin AS: The p65 (RelA) subunit of NF$\mathrm{kB}$ interacts with the histone deacetylase (HDAC) corepressors HDAC1 and HDAC2 to negatively regulate gene expression. Mol Cell Biol 2001, 21:7065-7077.

26. Mayo MW, Denlinger CE, Broad RM, Yeung F, Reilly ET, Shi Y, Jones DR: Ineffectiveness of histone deacetylase inhibitors to induce apoptosis involves the transcriptional activation of NF-kB through the Akt pathway. J Biol Chem 2003, 278:18980-18989.

27. Chen LF, Mu Y, Greene WC: Acetylation of RelA at discrete sites regulates distinct nuclear functions of NF-kB. EMBO J 2002, 21:6539-6548.

28. Hasala H, Zhang X, Saarelainen S, Moilanen E, Kankaanranta H: c-jun-Nterminal kinase mediates constitutive human eosinophil apoptosis. Pulm Pharmacol Ther 2007, 20:580-587.

29. Machida K, Inoue H, Matsumoto K, Tsuda M, Fukuyama S, Koto H, Aizawa H, Kureishi $Y$, Hara N, Nakanishi Y: Activation of PI3K-Akt pathway mediates antiapoptotic effects of $\beta$-adrenergic agonist in airway eosinophils. Am J Physiol Lung Cell Mol Physiol 2005, 288:L860-L867.

30. Simon HU: Cell death in allergic diseases. Apoptosis 2009, 14:439-446

31. Marks PA, Richon VM, Rifkind RA: Histone deacetylase inhibitors: inducers of differentiation or apoptosis of transformed cells. J Natl Cancer Inst 2000, 92:1210-1216.

32. Shao Y, Gao Z, Marks PA, Jiang X: Apoptotic and autophagic cell death induced by histone deacetylase inhibitors. Proc Natl Acad Sci USA 2004, 101:18030-18035.

33. Ishihara K, Hong J, Zee O, Ohuchi K: Possible mechanism of action of the histone deacetylase inhibitors for the induction of differentiation of HL60 clone 15 cells into eosinophils. Br J Pharmacol 2004, 142:1020-1030.

34. Han S, Lu J, Zhang Y, Cheng C, Li L, Han L, Huang B: HDAC inhibitors TSA and sodium butyrate enhanced the human IL-5 expression by altering histone acetylation status at its promoter region. Immunol Lett 2007, 108:143-50.

35. Furumai R, Komatsu Y, Nishino N, Khochbin S, Yoshida M, Horinouchi S: Potent histone deacetylase inhibitors built from trichostatin $\mathrm{A}$ and cyclic tetrapeptide antibiotics including trapoxin. Proc Natl Acad Sci USA 2001, 98:87-92.

36. Grozinger CM, Hassig CA, Schreiber SL: Three proteins define a class of human histone deacetylases related to yeast Hda1p. Proc Natl Acad Sci USA 1999, 96:4868-4873.

37. Tong JJ, Liu J, Bertos NR, Yang X-J: Identification of HDAC10, a novel class II human histone deacetylase containing a leucine-rich domain. Nucleic Acids Res 2002, 30:1114-1123.

38. Mai A, Massa S, Ragno R, Esposito M, Sbardella G, Nocca G, Scatena R, Jesacher F, Loidl P, Brosch G: Binding mode analysis of 3-(4-benzoyl-1methyl-1H-2-pyrrolyl)-N-hydroxy-2-propenamide: a new synthetic histone deacetylase inhibitor inducing histone hyperacetylation, growth inhibition, and terminal cell differentiation [abstract]. J Med Chem 2002, 45:1778.

39. Janka-Junttila M, Moilanen $\mathrm{E}$, Hasala $\mathrm{H}$, Zhang $\mathrm{X}$, Adcock I, Kankaanranta H: The glucocorticoid RU24858 does not distinguish between transrepression and transactivation in primary human eosinophils. $J$ Inflammation 2006, 3:10.

40. Kuendgen A, Knipp S, Fox F, Strupp C, Hildebrandt B, Steidl C, Germing U, Haas R, Gattermann N: Results of a phase 2 study of valproic acid alone or in combination with all-trans retinoic acid in 75 patients with myelodysplastic syndrome and relapsed or refractory acute myeloid leukaemia. Ann Hematol 2005, 84(suppl 1):61-66.

41. Hauschild A, Trefzer U, Garbe C, Kaehler K, Ugurel S, Kiecker F, Eigentler T, Krissel $H$, Schadendorf D: A phase II multicenter study on the histone 
deacetylase (HDAC) inhibitor MS-275, comparing two dosage schedules [abstract]. J Clin Oncol 2006, 24(suppl):8044.

42. Gojo I, Jiemjit A, Trepel JB, Sparreboom A, Figg WD, Rollins S, Tidwell ML, Greer J, Chung EJ, Gore SD, Sausville EA, Zwiebel J, Karp JE: Phase 1 and pharmacological study of MS-275, a histone deacetylase inhibitor, in adults with refractory and relapsed acute leukemias. Blood 2007, 109:2781-2790.

43. Garcia-Manero G, Assouline S, Cortes J, Kantarjian H, Yang H, Newsome WM, Miller WH Jr, Rousseau C, Kalita A, Liu J, Dubay M,

Patterson TA, Li Z, Besterman JM, Reid G, Laille E, Martell RE, Minden MD: Phase I study of the oral isotype specific histone deacetylase inhibitor MGCD0103 in leukemia. Blood 2008, 112:981-989.

44. Siu LL, Pili R, Duran I, Messersmith WA, Chen EX, Sullivan R, MacLean M, King S, Brown S, Reid GK, Li Z, Kalita AM, Laille EJ, Besterman JM, Martell RE, Carducci MA: Phase I study of MGCD0103 given as three-times-per-week oral dose in patients with advanced solid tumors. J Clin Oncol 2008, 26:1940-1947.

45. Walsh GM, Sexton DW, Blaylock MG: Mechanism of steroid action and resistance in inflammation: Corticoisteroids, eosinophils and bronchial epithelial cells: new insights into the resolution of inflammation in asthma. J Endocrinol 2003, 178:37-43.

doi:10.1186/1476-9255-7-9

Cite this article as: Kankaanranta et al:: Histone deacetylase inhibitors induce apoptosis in human eosinophils and neutrophils. Journal of Inflammation 2010 7:9.

\section{Submit your next manuscript to BioMed Central and take full advantage of:}

- Convenient online submission

- Thorough peer review

- No space constraints or color figure charges

- Immediate publication on acceptance

- Inclusion in PubMed, CAS, Scopus and Google Scholar

- Research which is freely available for redistribution

Submit your manuscript at www.biomedcentral.com/submit 